\title{
The influence of age on the xylose absorption test
}

\author{
MARTIN J. KENDALL \\ From the Queen Elizabeth Hospital, Birmingham
}

SUMMARY Xylose absorption tests were performed on patients unselected except to exclude gastrointestinal or renal disease. The proportion of xylose excreted decreases with increasing age. Intravenous xylose tests suggest that this is due to a deterioration in renal function rather than to a reduction in intestinal absorption.

Xylose is a pentose which is absorbed actively (Csáky and Lassen, 1964) from the jejunum. The pathway is similar to that of the hexoses (Alvarado, 1966) and therefore the xylose test is used to study the absorption of carbohydrate. It is easy to perform and, although part is metabolized, a fairly constant proportion is excreted in the urine and this reflects the amount absorbed (Fordtran, Soergel, and Ingelfinger, 1962). Although the test is widely used, its place in intestinal investigation and, in particular, its value in diagnosis remains uncertain. More precise interpretation of results would be possible if factors affecting it were better understood.

The effect of age is important for low values of xylose excretion may be obtained in the elderly (Fowler and Cooke, 1960; Texter, Cooper, Vidinli, and Finlay, 1964), and Vartio (1960) showed that the mean value for excretion after a dose of $25 \mathrm{~g}$ was significantly lower in those over 45. Guth (1968), however, found no significant decrease in xylose excretion with aging. The present study demonstrates the effect of age and the reasons for this.

\section{Patients and Methods}

An oral xylose absorption test was performed in 100 patients and an intravenous xylose excretion test in 85. Most were hospital patients in medical Received for publication 26 November 1969. wards, unselected except to exclude any with gastrointestinal disease or impaired renal function (blood urea under $40 \mathrm{mg} / 100 \mathrm{ml}$, serum creatinine under $1.3 \mathrm{mg} / 100 \mathrm{ml}$ ). The rest were hospital personnel and medical students.

ORAL TEST

The oral xylose absorption test was done as suggested by Sammons, Morgan, Frazer, Montgomery, Philip, and Phillips (1967). After an overnight fast $5 \mathrm{~g}$ of $\mathrm{D}$-xylose was given with $300 \mathrm{ml}$ water; urine was collected for the next two hours and the succeeding three hours in two separate bottles. The amount of xylose in urine decreases on standing. This was prevented by adding $20 \mathrm{ml}$ of $2.5 \%$ formaldehyde in isopropyl alcohol (hospital sterilizing solution) to the containers. This does not interfere with the estimation which was performed by the method of Roe and Rice (1948).

\section{INTRAVENOUS TEST}

Five g D-xylose was given as $50 \mathrm{ml}$ of a $10 \%$ solution intravenously over five minutes. No dietary restrictions were placed on the patient who was encouraged to drink enough to produce an adequate urinary output. This was collected as for the oral test in an initial two-hour and subsequent three-hour collection. There were no complications or side effects following the intravenous injection. 


\section{Results}

The results of the oral test are given in Tables I and II and are shown graphically in Figures 1 and 2 . The amounts excreted in the first two hours and in the total five hours are shown separately but both sets of results show clearly a decrease in the xylose excreted with each decade. The numbers in each decade are too small for satisfactory statistical analysis. However, differences

$\left.\begin{array}{lclll}\hline \text { Age } & \begin{array}{l}\text { Number of } \\ \text { Tests }\end{array} & \begin{array}{l}\text { Mean Xylose } \\ \text { Excretion }(\mathrm{g})\end{array} & \begin{array}{l}\text { Standard } \\ \text { Deviation }\end{array} & \text { Significance } \\ \hline 10-20 & 7 & 1.18 & 0.23 \\ 21-30 & 20 & 1.13 & 0.23 \\ 31-40 & 19 & 1.04 & 0.19 \\ 41-50 & 15 & 0.93 & 0.27 \\ 51-60 & 22 & 0.89 & 0.17 \\ 61-70 & 14 & 0.80 & 0.11 \\ \text { Over } 70 & 3 & 0.51 & 0.06\end{array}\right\} \quad \begin{aligned} & \text { Not significant } \\ & \text { P }\end{aligned}$

Table I Xylose excreted in two hours after $5 \mathrm{~g}$ taken orally

\begin{tabular}{|c|c|c|c|c|}
\hline Age & $\begin{array}{l}\text { Number of } \\
\text { Tests }\end{array}$ & $\begin{array}{l}\text { Mean Xylose } \\
\text { Excretion }(g)\end{array}$ & $\begin{array}{l}\text { Standard } \\
\text { Deviation }\end{array}$ & Significance \\
\hline $10-20$ & 7 & $2 \cdot 16$ & 0.34 ? & \\
\hline $21-30$ & 20 & 1.97 & $0.30\}$ & Not significant \\
\hline $31-40$ & 19 & 1.88 & $0.27\}$ ) & \\
\hline $41-50$ & 15 & 1.70 & 0.34 & $P<0.01$ \\
\hline $51-60$ & 22 & 1.59 & 0.247 & \\
\hline $61-70$ & 14 & 1.56 & $0.25\}$ & $P<0.01$ \\
\hline Over 70 & 3 & 0.99 & $0.23\}$ & \\
\hline
\end{tabular}

Table II Xylose excreted in five hours after $5 \mathrm{~g}$ taken orally

between alternate decades have been analysed by Student's $t$ test and, although these are not significant between the first three decades, thereafter differences between alternate decades are significant $(P<0.01)$.

The corresponding results of the intravenous excretion test are given in Tables III and IV and are shown in Figures 3 and 4. An obviously

$\left.\begin{array}{lllll}\hline \text { Age } & \begin{array}{l}\text { Number of } \\ \text { Tests }\end{array} & \begin{array}{l}\text { Mean Xylose } \\ \text { Excretion }(\mathrm{g})\end{array} & \begin{array}{l}\text { Standard } \\ \text { Deviation }\end{array} & \text { Significance } \\ \hline 10-20 & 10 & 2.09 & 0.43 \\ 21-30 & 9 & 1.93 & 0.37 \\ 31-40 & 14 & 1.96 & 0.25 \\ 41-50 & 15 & 1.73 & 0.29 \\ 51-60 & 19 & 1.51 & 0.29 \\ 61-70 & 15 & 1.41 & 0.31 \\ \text { Over } 70 & 3 & 0.97 & 0.27\end{array}\right\} \quad \begin{aligned} & \text { Not significant } \\ & \text { P }\end{aligned}$

Table III Xylose excreted in two hours after $5 \mathrm{~g}$ given intravenously

similar decline in the amount excreted as the age increases is shown. There is no significant difference between the first three decades in the amount excreted in either two or five hours. For the

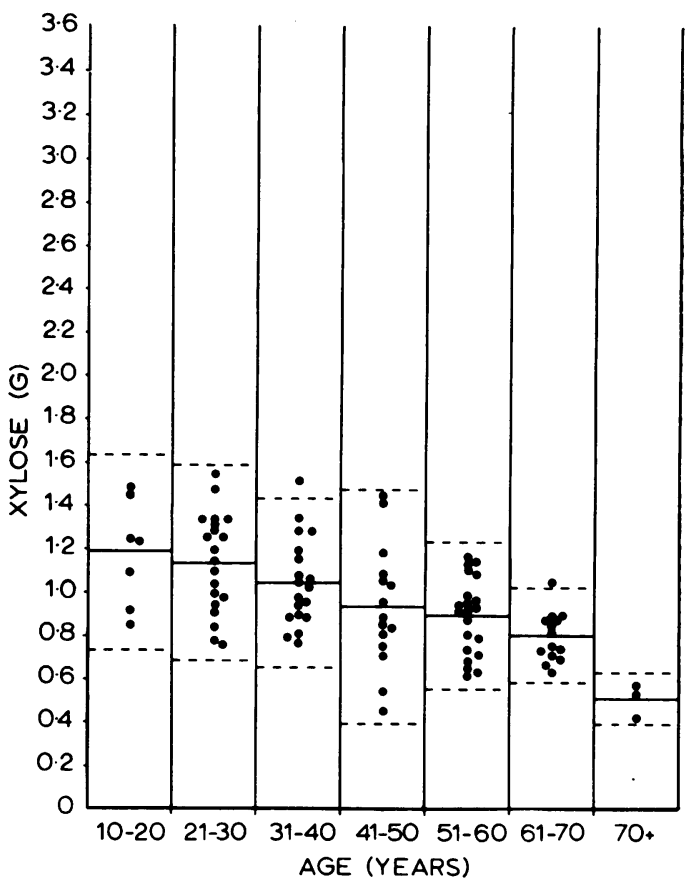

Fig. 1 Xylose excreted in two hours after $5 \mathrm{~g}$ orally showing the mean and 2 standard deviations for each decade.

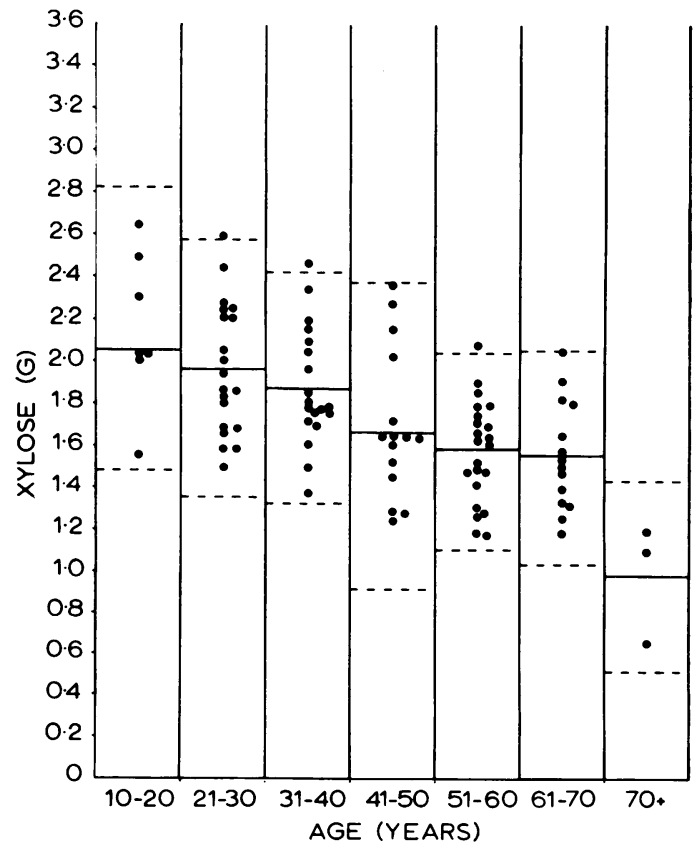

Fig. 2 Xylose excreted in five hours after $5 \mathrm{~g}$ orally showing the mean and 2 standard deviations for each decade. 


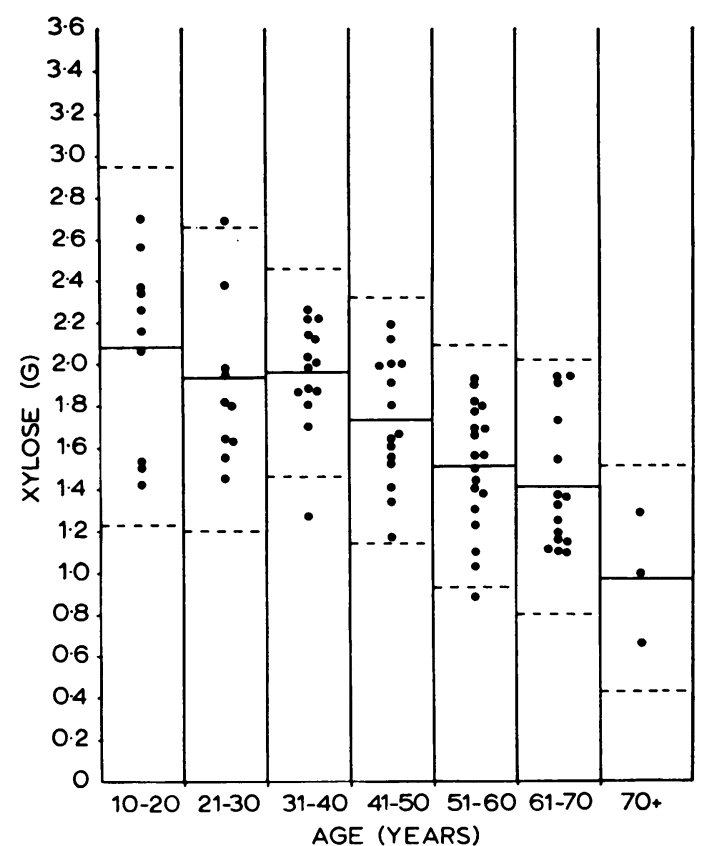

Fig. 3 Xylose excreted in two hours after $5 \mathrm{~g}$ intravenously showing the mean and 2 standard deviations for each decade.

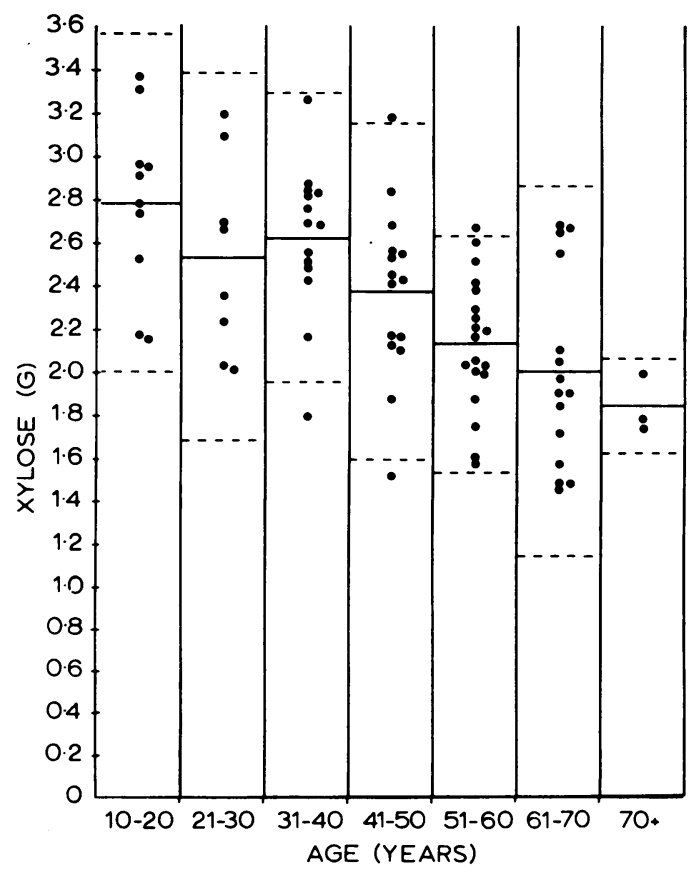

Fig. 4 Xylose excreted in five hours after $5 \mathrm{~g}$ intravenously showing the mean and 2 standard deviations for each decade.

\begin{tabular}{|c|c|c|c|c|}
\hline Age & $\begin{array}{l}\text { Number of } \\
\text { Tests }\end{array}$ & $\begin{array}{l}\text { Mean Xylose } \\
\text { Excretion }(g)\end{array}$ & $\begin{array}{l}\text { Standard } \\
\text { Deviation }\end{array}$ & Significance \\
\hline $\begin{array}{l}10-20 \\
21-30 \\
31-40 \\
41-50 \\
51-60 \\
61-70 \\
\text { Over } 70\end{array}$ & $\begin{array}{r}10 \\
9 \\
14 \\
15 \\
19 \\
15 \\
3\end{array}$ & $\begin{array}{l}2 \cdot 78 \\
2 \cdot 53 \\
2 \cdot 62 \\
2 \cdot 37 \\
2 \cdot 13 \\
2 \cdot 00 \\
1 \cdot 84\end{array}$ & $\left.\begin{array}{l}0.39 \\
0.42 \\
0.34 \\
0.39 \\
0.30 \\
0.43 \\
0.11\end{array}\right\}$ & $\begin{array}{l}\text { Not significant } \\
\mathbf{P}<0.01 \\
\mathbf{P}<0.01\end{array}$ \\
\hline
\end{tabular}

Table IV Xylose excreted in five hours after $5 \mathrm{~g}$ given intravenously

higher age groups the differences between alternate decades were significant.

\section{Discussion}

The amount of xylose excreted at both two and five hours after an oral dose decreases with age. This decline could be due to an effect on any stage of the test: from delayed gastric emptying, impaired absorption, increased metabolism, or deterioration in renal function. Faulty collection is a problem in the elderly though this is unlikely to be a factor in the present study. To eliminate the intestinal phase and to study the effect of age on the metabolism and excretion, the same dose of xylose was given intravenously. The similar decline in the amount of xylose excreted after the parenteral dose makes it very likely that a change in the metabolism or excretion is a major reason for the reduced xylose excretion with advancing age. An increase in the rate of metabolism is unlikely, whereas deterioration in renal function (Davies and Shock, 1950; Shock, 1958) and a rise in blood urea (Carmalt and Whitehead, 1969) are known to occur.

It would be difficult to exclude the possibility of a small deterioration in absorption with ageing. One can look at the effects of absorption and excretion further by expressing the amount excreted after an oral dose over the amount excreted in the same period after the same dose intravenously (oral/intravenous) as a percentage. A reduction in renal function will produce a proportionate decrease in the amount excreted however it has been administered and therefore

\begin{tabular}{|c|c|c|c|}
\hline \multirow[t]{2}{*}{ Age } & \multicolumn{2}{|c|}{ Xylose Excreted (percentage) } & \multirow[t]{2}{*}{ Mean Blood Urea } \\
\hline & After 2 hours & After 5 hours & \\
\hline $\begin{array}{l}10-20 \\
21-30 \\
31-40 \\
41-50 \\
51-60 \\
61-70\end{array}$ & $\begin{array}{l}56 \cdot 5 \\
58 \cdot 6 \\
66 \cdot 8 \\
53 \cdot 8 \\
58 \cdot 9 \\
56 \cdot 7\end{array}$ & $\begin{array}{l}77 \cdot 7 \\
77 \cdot 9 \\
71 \cdot 8 \\
71 \cdot 7 \\
74 \cdot 6 \\
78 \cdot 0\end{array}$ & $\begin{array}{l}19 \cdot 8 \\
25 \cdot 3 \\
24 \cdot 8 \\
27 \cdot 2 \\
28 \cdot 7 \\
29 \cdot 1\end{array}$ \\
\hline
\end{tabular}

Table V Xylose excreted after an oral dose expressed as a percentage of that excreted after an intravenous dose and the mean blood urea for each decade 
the oral/intravenous percentage will remain more or less constant. On the other hand, impaired absorption will produce a low value for the oral result whilst the intravenous one remains unaffected and thus the percentage oral/intravenous will be reduced. The oral/intravenous percentages obtained from the mean excretions for each decade show no real change with age whereas the mean blood urea rises (Table V).

Age is therefore important in interpreting the results of the xylose absorption test. Diminishing excretion with rising age indicates an ageing kidney and not failing intestinal absorption.

I thank Dr C. F. Hawkins for his help and encouragement in preparing this paper, Sheila Nutter for technical assistance, and the Queen Elizabeth Hospital pharmacists who prepared the intravenous xylose. The work was supported by a grant from the endowment fund of the United Birmingham Hospitals.

References

Alvarado, F. (1966). D-xylose active transport in the hamster small intestine. Biochim. biophys. Acta (Amst.), 112, 292306.

Csáky, T. Z., and Lassen, U. V. (1964). Active intestinal transport of D-xylose. Biochim. biophys. Acta (Amst.), 82, 215-217.

Carmalt, M. H. B., and Whitehead, T. P. (1969). Personal Communication.

Davies, D. F., and Shock, N. W. (1950). Age changes in glomerular filtration rate, effective renal plasma flow and tubular excretory capacity in adult males. J. clin. Invest., 29, 496507.

Fowler, D., and Cooke, W. T. (1960). Diagnostic significance of D-xylose excretion test. Gut, 1, 67-70.

Fordtran, J. S., Soergel, K. H., and Ingelfinger, F. J. (1962). Intestinal absorption of D-xylose in man. New Engl. J. Med., 267, 274-291.
Guth, P. H. (1968). Physiological alterations in small bowel function with age. Amer. J. dig. Dis., 13, 565-571.

Roe, J. H., and Rice, E. W. (1948). A photometric method for the determination of free pentoses in animal tissues. J. biol. Chem., 173, 507-512.

Sammons, H. G., Morgan, D. B., Frazer, A. C., Montgomery, R. D., Philip, W. M., and Phillips, M. J. (1967). Modification in the xylose absorption test as an index of intestinal function. Gut, 8, 348-353.

Shock, N. W. (1958). The role of the kidney in electrolyte and water regulation in the aged. Ciba. Fdn Colloq. Ageing, 4, 229-249.

Texter, E. C., Cooper, J. A. D., Vidinli, M., and Finlay, J. M. (1964). Laboratory procedures in the diagnosis of malabsorption. Med. Clin. N. Amer., 48, 117-136.

Vartio, T. (1960). D-xylose tolerance test in achlorhydria. Ann. Med. intern. Fenn., 49, 317-321.
ग 